\title{
Empirical Study of Relationship between Budget Deficits and Inflation: A Case Study of Pakistan
}

\author{
Riaz H. Soomro* and Asif Saeed Memon \\ SZABIST \\ Karachi, Pakistan
}

\begin{abstract}
The purpose of this study is to determine the empirical relationship between budget deficits and inflation based on CPI, and to find empirical evidence of sources of inflation in Pakistan, considering data from 1973 to 2006. The main source of data has been the State Bank of Pakistan and the Federal Bureau of Statistics. Univariate analysis along with simple statistical analysis is utilized to determine the time series properties of each variable. Ordinary Least Square (OLS) method is used to analyze the relationship between the variables of Interest. Co-integration and Error Correction Mechanism (ECM) are used to determine the long run and short run relationships respectively.

The results of this study indicate that there is a long run relationship between inflation and Budget Deficit to GDP Ratio (BDGR). Further sources of inflation in Pakistan have been budget deficits, GDP growth, and international inflation, reserve Money and weighted average lending rates. The implications are that tight monetary policy can serve as an effective anti-inflationary measure but a restrictive fiscal policy (reduction in government expenditures) can also help to minimize inflation in Pakistan.
\end{abstract}

\section{INTRODUCTION}

There has been a sharp increase in the level of prices for the last two years (see Figure 1). In the year 2004, rate of inflation was $7.4 \%$ and in 2005 , rate of inflation stood at $9.1 \%$. To understand the impact and dynamics of inflation carefully, generally, it is argued world wide that inflation is a net result of sophisticated and continuous interactions of demand-side (or monetary) shocks, supplyside (or real) shocks, price adjustment (or inertial) factors and political processes (or institutional factors). Sustainability of high and persistent inflation rates are usually because of the following reasons:

1) High budget deficits

2) Monetization of budget deficits

3) Massive infrastructure investments by city, provincial and federal governments

4) High military expenditures associated with geopolitical reasons

5) Political instability which results in inflationary pressures

6) Persistent inflationary expectations of economic agents

7) Inflationary effects of changes in exchange rates through increase in prices of imported inputs
8) Occasional increases in world prices of major imported inputs (particularly, crude-oil)

9) Increases in regulated prices of public sector products which are mainly used as input by the domestic private sector, and/or

10) Rising interest rates resulting from the crowdingout effect [1]

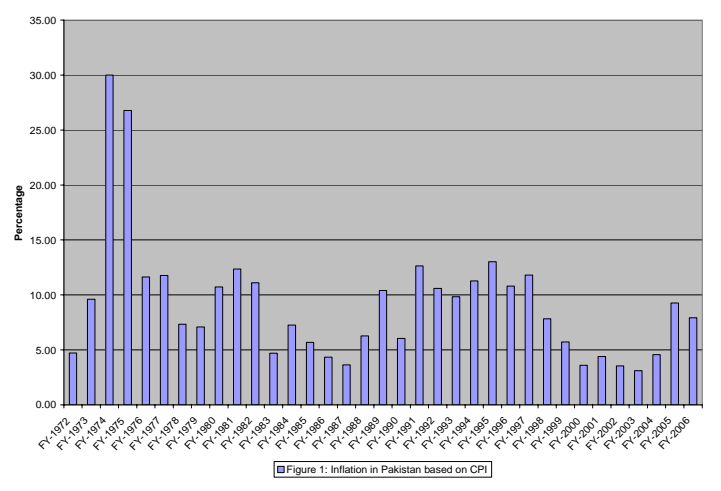

Figure 1: Source: Hand Book of Statistics on Pakistan Economy-2005 by State Bank of Pakistan

High inflation has been an issue of concern for Pakistan for many decades (see Figure 1). Rate of inflation has been more than 5\%, except in 1983, 1986 and 1987. This persistent rise in general level of prices leads us to study the model and analyze the sources of inflation in Pakistan.

Macroeconomic theory postulates that higher budget deficits cause inflation. What happens to the general level of prices when the fiscal deficits are created? The answer is inflation because deficits can be financed by increasing money supply. Theoretically, there exists a relationship between the two variables. Hamberger and Zwick have concluded that higher federal deficits are inflationary while studying the USA data [2]; such relationship is being tested for Pakistan. Further, the sources of inflation are also investigated and tested empirically.

\footnotetext{
* Faculty member of Indus Institute of Higher Education and perusing MS/Ph.D studies at SZABIST
} 


\section{OBJECTIVE OF THE STUDY}

The purpose of this study is to investigate empirically the impact of the federal budget deficits on inflation. Variables taken are Consumer Price Index (CPI) as proxy of inflation and Budget Deficit to Gross domestic product Ratio (BDGR). Inflation is the dependent variable and BDGR is the independent variable.

The study also empirically investigates the sources of inflation. For this purpose, independent variables taken in this study are: Import Prices (IMPP), real GDP growth rate (GDPR) and Weighted Average Lending Rate (WALR).

\section{HYPOTHESIS}

First, whether or not inflation is caused by the budget deficits?

Second, whether or not the sources of inflation are BGDR, IMPP, GDPR and WALR?

\section{REVIEW OF THE LITERATURE}

Three models of inflation became popular in economics namely, monetarists inflation model, inflation unemployment model and structural inflation model.

Monetarists' model stated that price change is the result of change in income to output ratio. Friedman, founder of monetarist theory, postulated that inflation everywhere is a monetary phenomenon [3].

Phillips curve model, which afterwards was formalized by Lipsy, stated that an economy could not simultaneously achieve inflation and unemployment [4].

Maynard and Rijckeghem argued through structural approach to economic model. They stated that differential rates in productivity growth; wages, income elasticity and prices between industrial and services sector determine the inflation [5]. Inflation model constructed should give true picture of theoretical propositions [6].

Various empirical studies have been done in this respect to determine the factors, which cause inflation. The literature review suggests that empirical controversy still surrounds the role that federal budget deficits play in the inflationary process in Pakistan and throughout world Even countries like the USA faced a similar situation in the early 80 's. For example, Darrat, while studying U.S. data, concluded that federal deficits have more reliable and stronger impact on inflation [7]. Barro found no empirical evidence supporting this claim [8]. For some countries, several empirical studies have found the inflationary problem to be caused essentially by non-monetary factors. Carmichael argued that such a claim remains a purely theoretical proposition requiring empirical verification [9].
Using Turkish data, covering post World War II, Akcay et al. concluded stable long run relationship between the budget deficits, money growth and inflation. The study suggested affirmative results [10].

In Pakistan, the subject has been studied intensively. As Naqvi and Khan pointed out that deficit exert indirect impact on inflation via induced changes in money supply [11]. Siddiqui found a two-way causal relationship between the money supply and inflation. He also concluded that money supply and inflation have common link with budget deficit [12]. Shabbir and Ahmad pointed out a positive and significant relationship between the inflation and budget deficit, and studied the direct and indirect impact of different variables on inflation. The contribution of budget deficit to money supply was underestimated in this research. [13].

Nasim found direct relationship between the money supply and inflation [14]. Husain and Abbas indicated price having small association with money [15]. Most of the research in Pakistan suffers from a common defect, that is, except Nasim, [14] they have ignored the stationary properties of the variable [16].

The famous study by Hasan et. al. pointed out the factors responsible for upsurge in rate of inflation in Pakistan. The paper consisted of theoretical description and estimation techniques. The paper pointed out that the factors which cause the inflation are various supply side shocks, international prices, government procurements, supported or administered prices and the emergence of stronger inflationary expectations in the economy. Contrary to the popular perception, they found that the contribution of supply shocks and monetary expansions to the rise in wholesale price was limited. According to them, the principal factor contributing to the inflation at that time was the increase in procurement prices and administrated prices. While these have been seen as once and for all changes, they have perhaps tended to produce a spiraling effect. Also, there has been a component of imported inflation and impact of rising inflationary expectations. They conclude that, it appears that during the fiscal year, a large number of factors have been operative in explaining the high rate of inflation in Pakistan. The stationary test reported, in this paper, that all variables are trend not mean stationary. The test of the configuration was also not done. Furthermore, the overall impact of the tax policy has not been shown in this paper, for example, the increase in sales tax has been shown but the reduction in the import duty has not been reported [6].

Choudhry and Anjum found that the domestic financing of the budget deficits, particularly from the banking sector, is inflationary in the long run [17]. They showed the positive relationship between budget deficits and inflation during acute inflation i-e 1970 and concluded that deficits also emerged as an endogenous variable [17]. The model developed by these authors was mis-specified, as the impact of imported price was not taken into account. 
Qayyum and Bilqees forecasted inflation based on leading indicator of inflation that is the P-Star Model. A different approach towards inflation modeling as P-Star Modeling is based on long-term quaintly theory of money and points and puts together long-term determinants of price level and short term changes in current inflation. But the approach is altogether a different approach than the autoregressive model and M2 Growth augmented model [18]. Data and methodology used in this paper is stated in the next section.

\section{DATA SOURCES AND METHODOLOGY}

Simple statistical analysis is utilized to determine the general properties of data from 1973-2006. The data is taken from 1973 onwards because the separation of East and West Pakistan took place in 1971. The two years are taken out to avoid irregularity in the times series analysis. These two years are considered as the years of stability.

The Univariate analysis is utilized for each variable to determine the data generating process, which means understanding the time series properties of each variable. Incase the variables are found to be stationary; we will use Ordinary Least Squares (OLS) method. OLS method is used in the regression analysis to assess the relationship between the variables of interest. However, if the variables are found to be non-stationary, say integrated of order one, we will utilize co-integration analysis to see if there is any long run relationship among the variables. Short run analysis will be made using error correction mechanism.

The data has been taken from 50 Years of Pakistan in Statistics 1998, published by the Federal Bureau of Statistics, Government of Pakistan [19], and various issues of Economic Survey by Ministry of Finance, Government of Pakistan [20]. However, the main source of data has been Hand Book of Statistics on Pakistan Economy 2005, by State Bank of Pakistan [21]. E-Views and ExcelStatistical software are used for empirical tests.

\section{MODEL SPECIFICATIONS AND RESULTS}

For the first part of the hypothesis, the model is specified as:

$$
\mathrm{LINFL}=\mathrm{f}(\mathrm{LBDGR})
$$

Where, LINFL $=$ Log of Inflation-Dependent Variable LBDGR $=$ Log of Budget Deficit to GDP RatioIndependent Variable

The confirmation that whether series should be transformed or not, was made by the power method.

LINFL $=0.9704+0.6647$ LBDGR

To give the definite conclusion about LINFL and LBGDR variables, it was found that both variables are integrated of order one. We checked the error term and concluded that error term was integrated of order zero that is I (0). It establishes that there is long-term relationship between INFL and BDGR. This also proves that the equation is not spurious. Coefficient is positive and statistically significant at $5 \%$ level. Since the INFL and LBDGR were found to be integrated of order one, therefore, we applied the Engel Granger co-integration test and calculated residuals. Residuals were found to be integrated of order zero. Breusch and Goldfrey-LM test showed affirmative results with significant $\mathrm{t}$ statistic. Breusch and Goldfrey-LM suggested that both variables are co-integrated. Further, the test of causality suggested federal deficits unidirectional Granger-cause inflation.

Empirical equation-2 shows that federal deficits have strong impact on inflation. It means that while making attempts to reduce the inflation in Pakistan, we cannot ignore a restrictive fiscal policy; may be by reducing the government expenditures.

While attempting to explore the reasons of inflation, we estimate the equation with the help OLS method.

The dependent variable is LCPIN and independent variables are LBDGR, LGDPR, LRESM, LIMP and LRESM.

$$
\begin{gathered}
\mathrm{LCPIN}=\alpha+\alpha_{1} \text { LBDGR }+\alpha_{2} \text { LGDPR }+\alpha_{3} \text { LRESM }+ \\
\alpha_{4} \text { LIMPP }+\alpha_{5} \text { LWALR }
\end{gathered}
$$

Where, $\mathrm{LCPIN}=\mathrm{Log}$ of Consumer Price Index Number LBDGR $=$ Log of Budget Deficit to GDP Ratio LGDPR $=$ Log of Real Gross Domestic Product LRESM $=$ Log of Reserve Money LIMPP $=$ Log of Import Prices in PKR LWALR $=$ Log of Weighted Average Lending Rate

We run the equation with OLS method and got the following equation:

$$
\begin{gathered}
\mathrm{LCPIN}=0.058 \text { LBDGR }-0.35 \text { LGDPR }+0.48 \text { LIMPP } \\
\begin{array}{c}
\left(1.45^{*}\right) \\
+0.22 \text { LRESM }+0.23 \text { LWALR }
\end{array} \\
(2.88) \\
\left(\mathrm{R}^{2}=0.9962\right)
\end{gathered}
$$

The Durbin Watson (DW) is not applicable because constant is not included in the series; and DW-h test is applicable for the test which proved that the model does not suffer from Serial Correlation/Auto Correlation. Serial correlation has been removed from the series.

Augmented Dickey Fuller (ADF) statistic of all the variables shows the respective order of integration and confirms the presence of unit root at level difference of five percent level of Significance (See Table 1). Most of the series were found to be integrated of order one - I (1). 
To estimate proposed model empirically, the leg length of each explanatory variable was determined.

The resulting estimates are unbiased but still significant.

Table 1: Augmented Dicky-Fuller Test for Unit Root

$$
\Delta \mathrm{y}_{\mathrm{t}}=\mathrm{c}_{1}+\mathrm{by}_{\mathrm{t}}-1+\mathrm{C} 2 \mathrm{t}+\sum_{\mathrm{K}=1}^{\mathrm{p}} \mathrm{d}_{\mathrm{k}} \Delta \mathrm{y}_{\mathrm{t}-\mathrm{k}}+\mathrm{v}_{\mathrm{t}} ; \mathrm{H}_{0}: \mathrm{b}=0 ; \mathrm{H}_{\mathrm{a}}: \mathrm{b}>0
$$

\begin{tabular}{|c|c|c|c|c|c|c|c|}
\hline \multicolumn{8}{|c|}{ Unit Root Analysis at Logarithm Levels } \\
\hline Variables & Constant & $\begin{array}{c}\text { Constant and } \\
\text { Trend }\end{array}$ & None & $\mathbf{k}$ & .05 Level & .05 Level & .05 Level \\
\hline LCPIN & -0.5038 & -1.52688 & $3.595127^{*}$ & 2 & -2.9627 & -3.567 & -1.9526 \\
\hline LBDGR & -1.41914 & -2.330133 & -0.662217 & 1 & -2.9591 & -3.5614 & -1.9521 \\
\hline LGDPR & -2.11405 & -0.321356 & $3.397866^{*}$ & 1 & -2.9591 & -3.5614 & -1.9521 \\
\hline LRESM & -2.27655 & -1.583671 & $4.286035^{*}$ & 1 & -2.9591 & -3.5614 & -1.9521 \\
\hline LIMPP & -0.50084 & $-3.641066^{*}$ & $3.425229 *$ & 1 & -2.9591 & -3.5614 & -1.9521 \\
\hline LWALR & -0.13163 & 1.207825 & -1.129027 & 1 & -2.9591 & -3.5614 & -1.9521 \\
\hline LINFL & -2.66822 & -2.668224 & -1.174704 & 1 & -2.9591 & -3.5614 & -1.9521 \\
\hline \multicolumn{8}{|c|}{ Unit Root Analysis at First Difference Levels } \\
\hline Variables & Constant & $\begin{array}{c}\text { Constant and } \\
\text { Trend } \\
\end{array}$ & None & $\mathbf{k}$ & .05 Level & .05 Level & .05 Level \\
\hline LCPIN & -2.54984 & -2.482717 & -0.979693 & 2 & -2.9665 & -3.5731 & -1.953 \\
\hline LBDGR & $-4.9825^{*}$ & -4.822079 & $-4.90023 *$ & 1 & -2.9627 & -3.567 & -1.9526 \\
\hline LGDPR & -2.56005 & $-3.691858^{*}$ & -0.604142 & 1 & -2.9627 & -3.567 & -1.9526 \\
\hline LRESM & $-3.4143 *$ & $-4.522026^{*}$ & -0.662212 & 1 & -2.9627 & -3.567 & -1.9526 \\
\hline LIMPP & $-7.1064 *$ & $-6.825707^{*}$ & $-2.66822 *$ & 1 & -2.9627 & -3.567 & -1.9526 \\
\hline LWALR & -0.31816 & -0.90042 & $-0.28056^{*}$ & 1 & -2.9627 & -3.567 & -1.9526 \\
\hline LINFL & $-4.6234^{*}$ & $-4.661328 *$ & $-4.62258^{*}$ & 1 & -2.9627 & -3.567 & -1.9526 \\
\hline
\end{tabular}

Source: State Bank of Pakistan and Federal Bureau of Statistics, Government of Pakistan

Note: * denotes significance at the 5\% level and the rejection of the null hypothesis of non-stationary Critical values obtained from Fuller (1976)

Estimates are statistically inefficient. The empirical estimates which indicate the close fit as $99 \%$ variation is explained by the equation. As equation suggests that the role of LBDGR is not tight enough to affect the LCPI. The 
cumulative impact of LRESM on the LCPI is larger than the LBDGR. Impact of Imports Prices is larger than the Money Supply. The results do suggest that monitory growth, federal deficit, import prices and weighted average lending rate have significant impact on the CPI. This study suggests that while emphasizing on the restrictive fiscal policy, a tight monetary policy will also be mandatory to avoid the evil of inflation.

\section{CONCLUSION}

The study has empirically answered the question of whether or not Pakistan's inflation is significantly related to budget deficit. Model developed for this study is in consonance with economic theory. Further, while studying the sources of inflation the results does suggest that monitory growth, federal deficit, import prices and weighted average lending rate have significant impact on the CPI. Although decrease in imports and decrease in budget deficits can mitigate inflation significantly. Restrictive fiscal policy along with tight monetary policy appears to be an important and necessary ingredient in anti-inflation policy.

\section{REFRENCES}

[1] Kibritçioğlu, A., et al. "Causes of Inflation in Turkey: A Literature Survey with Special Reference to Theories of Inflation", in Inflation and Disinflation in Turkey, pages 43-76, 2002.

[2] Hamberger, M. J. and B. Zwick. "Deficits, Money and Inflation", Journal of Monetary Economics 7: pages 141-150, 1981.

[3] Friedman, Milton. "The Role of Monetary Policy", American Economic Review 58: pages 1-17, 1968.

[4] Lipsy, Richard. "The Relationship between Unemployment and Rate of Change of Money Wage Rates in United Kingdom 1862-1957: A Further Analysis", Economica 27: pages 1-31, 1960.

[5] Maynard, Geoffrey and Willy Van Rijckeghem. A World of Inflation, Batsford, New York, 1976. Retrieved from website: www.sagebub.com on December 12, 2005.

[6] Hasan, Aynul. M. et al. "What Explains Current High Rate of Inflation in Pakistan?" The Pakistan Development Review 34: 4, pages 927-943, 1995.

[7] Darrat, Ali F. "Inflation and Federal Budget Deficits: Some Empirical Results", Finance Quarterly 13: 2, pages 206-215, 1985.

[8] Barro, R. J. "Comment from an Unreconstructed Ricardian". Journal of Monetary Economics 4: pages 569-581, 1978.
[9] Carmichael, J. “On Barro's Theorem of Debt Neutrality: The Irrelevance of Net Wealth", American Economic Review 72: pages 202-213, 1982.

[10] Akcay O, Celdet et. al. "Budget Deficits Money Supply and Inflation: Evidence from Low and High Frequency Data for Turkey". Istanbul, Bogazici University, 1996. Retrieved from website: http://www.econ.boun.edu.tr/papers/pdf/wp-96-12.pdf of Bogazici University on March 2006.

[11] Naqvi, Syed Nawab Haider, and Ashfaque Haider Khan. "Inflation and Growth: An Analysis of Recent Trends in Pakistan", Pakistan Institute of Development Economics, 1989.

[12] Siddiqui Anjum. "Money and Inflation in Pakistan: Some Tests", The Indian Economic Journal 38: 1, 1990.

[13] Shabbir, Tayyab and Ayaz Ahmed. "Are Government Budget Deficits Inflationary? Evidence from Pakistan?" The Pakistan Development Review 33: 4, pages 955-967, 1994.

[14] Nasim, Anjum. "Determinants of Inflation in Pakistan”, State Bank of Pakistan, 1995.

[15] Husain, Fazal and Kalbe Abbas. "Income, Money, and Prices in Pakistan: Trends and Interrelationship", The Pakistan Development Review 39: 4, Part II, pages 843-855, 2000.

[16] Khan, Ashfaque H. and Mohammad Ali Qasim. "Inflation in Pakistan Revisited", The Pakistan Development Review 35: 4, Part II, pages 747-759, 1996.

[17] Choudry, Muhammad Aslam and Anjum Shahid Waseem. "Macro Economic Policies and Management of Debt, Deficit, and Inflation in Pakistan", The Pakistan Development Review 35: 4, Part II, pages 773-786, Winter 1996.

[18] Qayyum, Abdul and Faiz Bilquess. "P-Star Model: A Leading Indicator of Inflation for Pakistan", The Pakistan Development Review 39: 4, Part II, pages 843-855, 2005.

[19] "50 Years of Pakistan", Federal Bureau of Statistics, Government of Pakistan, 1998.

[20] Economic Survey, Ministry of Finance (Various Issues), Government of Pakistan.

[21] Hand Book of Statistics on Pakistan Economy, State Bank of Pakistan, 2005. 